\title{
The Surinam Disease. A Condition of Elephantiasis of the Banana caused by Ustilaginoidella oedipigera.
}

\author{
BY
}

ED. ESSED, B.Sc. (Edin.).

With Plate XXX.

LONG with the Panama disease, another plague was for a long time
known to occur, though rarely, on banana fields in Surinam, but, as in the case of the Panama disease, it only attracted attention when large areas were stocked with banana, and the damage done, although less serious than that caused by the Ustilaginoidella musaeperda, was found to interfere with the output of the banana plantations. According to the manager of the United Fruit Co., Mr. Goldsmith Williams, this disease also made its appearance in Columbia, but, as here, it does not alarm the planters very much.

The disease manifests itself by a very often enormous distension of the base of the stem - this is why it was called 'bigie footoe' or Elephantiasis. In some cases it may not be apparent, but generally a kind of sloughing takes place, caused by the transverse rupturing of the leaf-bases along the line of insertion. The leaves then wither; the withering has nothing striking about it; it is the ordinary fading away of dying leaves. In scrutinizing them, small pegmatia (mycocecidia) may be found to have run out at the surface along the margins of injuries on the midrib and the blade, some having made their own way through the epidermis. The apex of the rhizome may remain growing for some time after the outer leaves are destroyed, but the young leaves do not fully develop, and become highly chlorotic. In this stage the entire stem-portion of the plant can be severed from the underground part by simply pushing it down; it ruptures transversely along the bases of the leaves. When an attempt is made to push down a banana stem killed by Panama disease, it can only be caused to bend, but never to break down along the leaf-bases. This is an important difference in the external symptoms of the two diseases.

Sections through the rhizome showed that the fungus attacks at first the parenchyma and the prosenchymatous cells of the peripheral upper region (see Pl. XXX, Fig. I). So it was seen that the sloughing of the basal part was 


\section{Essed.-The Surinam Disease. A Condition of Elephantiasis}

probably due to tension in the tissues caused by the huge amount of hyphae pushing through to the basal air-spaces and sheaths of the leaves, and to the slow disintegration under the influence of the enzymic secretion before or during the forming of pegmatia. Under ordinary circumstances, the lining of the basal air-spaces of the leaves show a corrugated whitish appearance, due to the desiccation and throwing off of the lining cells; but when the fungus is feeding on the banana, and hyphae are running to the air-spaces, the process is accelerated and intensified, and the lining becomes a yellowish, granulo-caseous substance, due to the breaking away of a large amount of hardened yellow slime cells, stimulated by the fungus, in some of which spores may be seen to arise. The swelling of the base of the stem proved to be brought on by metaplastic changes in the tissues.

Although the germ tubes of spores were not found actually penetrating the rhizome anywhere, it was seen that hyphae were running horizontally and moving centripetally not very much below the base of the outermost leaves. So it looks very probable that the infection takes place here, where the young cells with comparatively thin walls facilitate the entrance of the fungus; then, if the mycelium spreads through the upper peripheral parts of the rhizome at first, and if we consider that new buds on the rhizome in the most cases arise in the lower underground portion, it is readily explained why the propagation of the disease within a 'hill' may be checked by carefully removing a diseased member. Moreover, if the mycelium can only penetrate the base of the outermost leaves in a comparatively young condition, then it will be plain that the chances of infection are very much restricted, and it will at once explain why the disease is so slow in spreading.

Pure cultures were raised in the way followed in isolating the Ust. musaeperda. Here, again, the same bacterium appeared on the cultures, showing convincingly that this bacterium is an ordinary soil bacterium and not pathogenic at all. The young mycelium most strikingly resembled that of the Ust.musaeperda, but later on, when the reproductive development sets in, the differences become apparent (see Fig. 2).

Pegmatia. The only difference, but surely not essential, is the rather conical shape of the chlamydosporangioid pegmatia. All the other kinds of pegmatia are identical with those of the foregoing fungus.

Spores. The chlamydospores do not differ in their mode of origin and their outlines, but they are somewhat smaller, nearly always greenish brown. The oidia are about the same. The only essential difference, by which also the relation to the Ust. musaeperda is defined, lies in the conidia. In the Ust. oedipigera we meet with I- and 2-cellular, very seldom 3-cellular, conidia; they are plumper and rather sausage-shaped, grouped in heads, which are kept together by a drop of hyaline mucilage. The branching is the same, but here we find an even greater tendency to become verticillate (see Fig. 3). 
of the Banana caused by Ustilaginoidella oedipigera. 365

Haustoria. I only met with the most simple type found in Ust. musaeperda, viz. the flat, saucer-shaped haustoria.

Psendo-pycnidia. Those found in the Ust.oedipigera are not so circumscript as those of the Ust. musaeperda. They contained, as in the latter, mainly chlamydospores.

Mycocecidia. These structures did not present any difference.

Enzymes. Here, again, we are faced by two enzymes of similar action. I must call attention to the fact that the action of the proteolytic enzyme is far less apparent than in the former fungus; it did not prove capable of softening the hyphal walls, as was seen in the first case; but since the same changes do take place in the one case as in the other, it is plain that the conditions under which the enzyme is acting in the plant are different from those under which the experiment is carried out.

Hyphal walls. These were found to be composed of chitin, with a small percentage of reducing carbohydrate. No pectin could be demonstrated.

The results of the inoculation experiments will be communicated later on.

Final remarks. At the start I said that the disease is not a serious one, because it does not spread to any extent, but it becomes even less so when it proves to be easily coped with. At least, the manager of the United Fruit Co., who had been experimenting for some time with $\mathrm{CuSO}_{4}$ solution, found it capable of perfectly checking the spreading of the disease. And that is what might be expected in the light of what was said before as to the way in which infection takes place. For if it occurs at the base of the outer leaves, i. e. epigeally, then it is easily understood how the spores, \&c., lying on or little below the surface of the soil, may be easily destroyed with a $\mathrm{CuSO}_{4}$ solution of sufficient strength.

\title{
EXPLANATION OF FIGURES IN PLATE XXX.
}

\author{
Illustrating Mr. E. Essed's paper on the Surinam Disease, a condition of \\ Elephantiasis of the Banana.
}

Fig. I. Section through base of leaf, explained in text. $\times 255$.

Fig. 2. (a) Branching of mycelium; (b) slimy exudation from tips of hyphae; (c) chain of chlamydospores and oidia.

Fig. 3. Conidial fructification. 


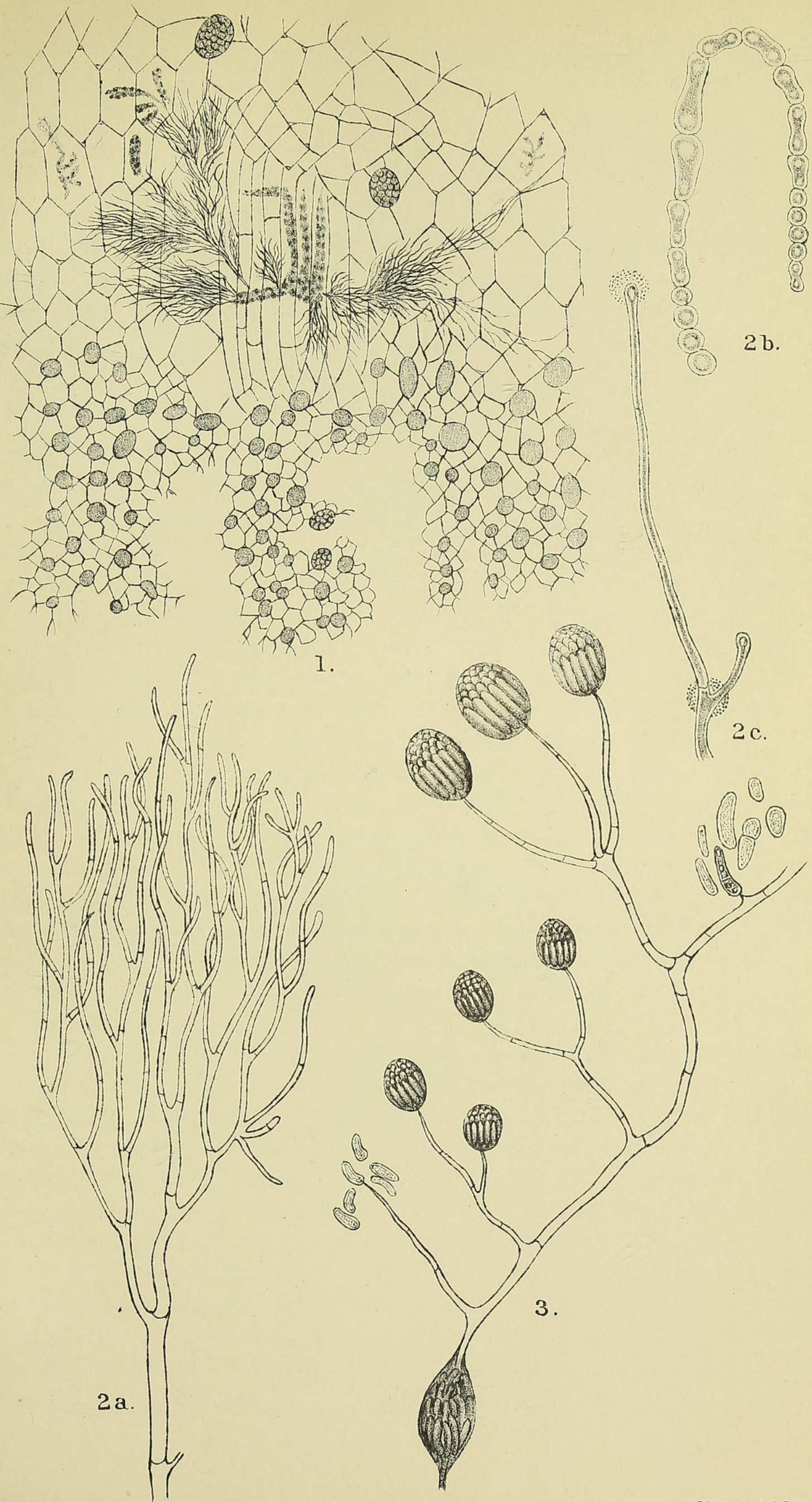




\section{$2 \mathrm{BHL}$ Biodiversity Heritage Library}

Essed, E. 1911. "The Surinam disease. A condition of elephantiasis of the banana caused by Ustilaginoidella oedipigera." Annals of botany 25, 363-365. https://doi.org/10.1093/oxfordjournals.aob.a089331.

View This Item Online: https://www.biodiversitylibrary.org/item/236971

DOI: https://doi.org/10.1093/oxfordjournals.aob.a089331

Permalink: https://www.biodiversitylibrary.org/partpdf/319839

\section{Holding Institution}

Smithsonian Libraries

\section{Sponsored by}

Biodiversity Heritage Library

\section{Copyright \& Reuse}

Copyright Status: Not in copyright. The BHL knows of no copyright restrictions on this item.

This document was created from content at the Biodiversity Heritage Library, the world's largest open access digital library for biodiversity literature and archives. Visit BHL at https://www.biodiversitylibrary.org. 